\title{
Cotton Seedling Preemergence Damping-Off Incited by Rhizopus oryzae and Pythium spp. and Its Biological Control with Trichoderma spp.
}

\author{
C. R. Howell
}

U.S. Department of Agriculture, Agricultural Research Service, Southern Plains Agricultural Research Center, 2765 F\&B Road, College Station, TX 77845.

Accepted for publication 1 November 2001.

\begin{abstract}
Howell, C. R. 2002. Cotton seedling preemergence damping-off incited by Rhizopus oryzae and Pythium spp. and its biological control with Trichoderma spp. Phytopathology 92:177-180.

Planting the cotton cv. Sure-Grow 747 in cotton seedling disease plots during the 2001 growing season resulted in high levels of preemergence damping-off among the seedlings. Four cotton pathogens, Pythium aphanidermatum, P. ultimum, an unidentified Pythium sp., and Rhizopus oryzae, were isolated from diseased seed embryos and seedlings. Disease incited by the Pythium spp. could be controlled by seed treatment with Metalaxyl, but disease incited by $R$. oryzae could not. Seed treatment with Metalaxyl in naturally infested field soil was only partially effective; therefore, symptoms in $47 \%$ of the diseased seedlings could be at-

tributed to $R$. oryzae. Susceptibility to disease appeared to be related to release in the spermosphere, by the germinating seeds, of compounds that stimulate pathogen propagule germination, because exudates from seed of the suscept Sure-Grow 747 and extracts from wheat bran induced pathogen germination and growth, whereas exudates from resistant cv. Stoneville 213 did not. However, even Stoneville 213 became susceptible when infested soil was amended with wheat bran. Seed treatment with preparations of Trichoderma virens parent, mutant, and hybrid strains gave effective biological control of preemergence damping-off. Disease control was attributable to metabolism by the biocontrol agent of pathogen germination stimulants released by the seed, because amendment of pathogen-infested soil with the propagule germination stimulants in wheat bran negated the protective effect of the seed treatment.
\end{abstract}

Seedling diseases of cotton are among the most important of those diseases that limit cotton lint and seed production. In 2001, the estimated loss in bales of cotton due to seedling diseases was $2.43 \%$, or approximately $\$ 169,820,640$ (2). Recent field and growth chamber tests with cotton cv. Sure-Grow 747, planted in soil from the seedling disease plots at College Station, TX, have resulted in high levels of preemergence damping-off among the seedlings. Symptoms of preemergence damping-off are most often observed under conditions of low temperature and high soil moisture at planting, and are usually attributed to the presence of Pythium spp. in the soil (6). Preemergence damping-off of cotton has been associated with the stimulation of the sporangia germination of P. ultimum by volatiles (11), exudates (12), and extracts (13) from cotton seed. Increased root exudation from beans induced by glyphosate treatment also has been associated with increased colonization of beans roots by P. ultimum (10). The standard chemical treatment for control of seedling disease incited by Pythium spp. has been seed or soil application of the fungicide Metalaxyl (15), and biological control of P. ultimum has been effected through seed and soil treatment with Trichoderma virens preparations $(7,8,16)$.

This year (2001), the soil was not excessively moist and the temperature was not unusually low (unpublished data). In addition, the fungicide Metalaxyl was only partially effective in controlling the disease, whereas biological control with Trichoderma spp. was very effective. This gave rise to the suspicion that Pythium spp. were not the only pathogens involved in the observed disease phenomenon.

Corresponding author: C. R. Howell; E-mail address: chowell@cpru.usda.gov

Publication no. P-2001-1217-04R

This article is in the public domain and not copyrightable. It may be freely reprinted with customary crediting of the source. The American Phytopathological Society, 2002.
The objectives of this study were to ascertain what pathogen or pathogens were responsible for inciting the observed disease symptoms, how cultivar and soil amendment contributed to the disease syndrome, and what mechanisms were employed by the Trichoderma spp. to affect disease control.

\section{MATERIALS AND METHODS}

Isolation and identification of cotton seedling pathogens in soil from seedling disease plots. Test tubes, containing $1 \mathrm{ml}$ of distilled water and $5 \mathrm{~g}$ of Lufkin fine sandy loam soil from the seedling disease plots, were each planted with one seed of cotton cv. Sure-Grow 747 (Sure-Grow Seed Inc., Centre, AL), that was either treated or not treated with the fungicide Metalaxyl $(22.2 \mathrm{ml}$ per $45.4 \mathrm{~kg}$ ). The seeds were covered with an additional $5 \mathrm{~g}$ of soil and incubated at $25^{\circ} \mathrm{C}$ for 4 to 5 days. Those seeds that did not emerge were harvested and the seed coats were removed. The embryos and radicles were washed with sterile distilled water and plated on potato dextrose agar (Difco Laboratories, Detroit, MI) containing $50 \mathrm{ppm}$ of rifampicin (Sigma-Aldrich, St. Louis). After 24 to $48 \mathrm{~h}$ at $25^{\circ} \mathrm{C}$, the cultures were examined for the presence of fungal colonies. Hyphal tips from colonies growing from infected seed were transferred to fresh rifampicin potato dextrose agar and incubated for 3 days at 13 and $37^{\circ} \mathrm{C}$. Those colonies showing no readily identifiable propagules were subtransferred to liquid still cultures of V8 cholesterol medium (1) and incubated for 10 days at $25^{\circ} \mathrm{C}$. The cultures were monitored periodically under the microscope for the presence of sexual structures. After the appearance of sexual structures, the isolates, and those that were already sporulating on the agar medium, were identified to species (3).

Confirmation of isolate pathogenicity to cotton seedlings of Sure-Grow 747. One mycelial mat from a 10-day-old V8 cholesterol still culture of $P$. aphanidermatum, P. ultimum, or Pythium sp. was macerated in $25 \mathrm{ml}$ of distilled water for $1 \mathrm{~min}$ in a Waring blender (model 33BL79; Dynamics Inc., New Hartford, 
CT). Aliquots $(10 \mathrm{ml})$ of each macerate were mixed, separately, into $1-\mathrm{kg}$ lots of noninfested Lufkin fine sandy loam mixed with $40 \%$ washed sand. The contents of two agar plates of mycelia and sporangia from Rhizopus oryzae were also mixed into $1 \mathrm{~kg}$ of noninfested soil/sand mix. Test tubes (five each) containing $10 \mathrm{~g}$ of moist soil infested with $P$. aphanidermatum, $P$. ultimum, Pythium sp., or $R$. oryzae were planted with untreated seed of cotton cv. Sure-Grow 747. The control was noninfested soil planted with untreated seed. The tubes were incubated at $25^{\circ} \mathrm{C}$ and a $14-\mathrm{h}$ photoperiod in a growth chamber for 7 days, after which the number of surviving seedlings was counted. Tubes containing soil infested with the above isolates also were planted with Sure-Grow 747 seed treated with Metalaxyl and incubated as described above. Each five-tube treatment was replicated three times, and the experiments were repeated. Seed from samples of the above tubes were harvested, cultured, and examined for the presence of fungal colonies as described in the previous section.

Effect of seed treatment, cotton cultivar, and soil amendment on preemergence damping-off in pathogen-infested field soil. Test tubes (five each), containing $10 \mathrm{~g}$ each of a mix consisting of $60 \%$ seedling disease plot soil and $40 \%$ washed sand, were planted with Sure-Grow 747 seed treated with Metalaxyl $(22.2 \mathrm{ml}$ per $45.4 \mathrm{~kg}$ ), wheat bran plus peat moss (WB+PM) preparations (8) of $T$. virens parent G-6, an antibiotic and mycoparasitic deficient mutant G6-5, T. virens $\times$ T. longibrachiatum fusant strains Tvl-30 and Tvl-35, or nontreated. Tubes containing the same soil mix amended with $1 \%$ wheat bran also were planted with Sure-Grow 747 seed treated as above. In addition, tubes containing amended and nonamended soil as described above were planted with seed of cotton cv. Stoneville 213. Tubes containing nonamended soil also were planted with Sure-Grow 747 seed coated with autoclaved preparations of $T$. virens strain G-6 and the fusant Tvl-30. All tubes were incubated in a growth chamber as previously described, and the numbers of surviving seedlings were counted. Each treatment was replicated three times, and the experiment was repeated.

Effect of seed exudates and wheat bran extract on pathogen propagule germination and growth. Seed lots $(30 \mathrm{~g})$ of cotton cvs. Sure-Grow 747 and Stoneville 213 were surface sterilized with $1 \%$ sodium hypochlorite in $70 \%$ ethanol for $5 \mathrm{~min}$, and washed with sterile water. Each seed lot was suspended in $90 \mathrm{ml}$ of sterile distilled water and shaken for $24 \mathrm{~h}$ at $150 \mathrm{rpm}$ on a G 10 gyratory shaker (New Brunswick Scientific Co. Inc., New Brunswick, NJ). The suspensions were filtered through Whatman No. 1 filter paper, autoclaved for $15 \mathrm{~min}$ at $121^{\circ} \mathrm{C}$, and stored aseptically at $-20^{\circ} \mathrm{C}$. Ground wheat bran $(30 \mathrm{~g})$ was suspended in

TABLE 1. Effect of seed treatment, cotton cultivar, and soil amendment on preemergence damping-off in soil naturally infested with Pythium aphanidermatum, Pythium sp., P. ultimum, and Rhizopus oryzae

\begin{tabular}{lcc}
\hline & \multicolumn{2}{c}{ Percent kill in pathogen-infested soil } \\
\cline { 2 - 3 } Treatment $^{\mathrm{y}}$ & Nonamended soil & Amended soil $^{\mathrm{z}}$ \\
\hline G-6, SG 747 & $20 \mathrm{~b}$ & $100 \mathrm{a}$ \\
G6-5, SG 747 & $13 \mathrm{ab}$ & $100 \mathrm{a}$ \\
Tvl-30, SG 747 & $0 \mathrm{a}$ & $93 \mathrm{ab}$ \\
Tvl-35, SG 747 & $13 \mathrm{ab}$ & $100 \mathrm{a}$ \\
Metalaxyl, SG 747 & $53 \mathrm{c}$ & $47 \mathrm{c}$ \\
NT, SG 747 & $93 \mathrm{~d}$ & $100 \mathrm{a}$ \\
NT, ST 213 & $7 \mathrm{ab}$ & $93 \mathrm{ab}$ \\
\hline
\end{tabular}

$\mathrm{x}$ Treatments are combinations of fungicide or biocontrol agent and cotton cultivar. $\mathrm{NT}=$ nontreated control. $\mathrm{SG}=$ Sure-Grow; ST = Stoneville. G-6 and G6-5 are Trichoderma virens strains; Tvl-30 and Tvl-35 are fusants of G-6 and T. longibrachiatum strain AK6-12.

y Numbers given are the averages of three replications. Means in a column followed by different letters are significantly different according to the protected least significant difference test at $\propto=0.05$, using general linear models (SAS Institute, Cary, NC).

${ }^{\mathrm{z}}$ Pathogen-infested soil was amended with $1 \%$ ground wheat bran.
$150 \mathrm{ml}$ of sterile distilled water and heated to boiling while stirring. The suspension was centrifuged at 3,000 $\times g$ for $10 \mathrm{~min}$ in a centrifuge (C4-12; Jouan, Inc., Winchester, VA). The supernate was also autoclaved and stored aseptically at $-20^{\circ} \mathrm{C}$.

Mycelial macerates of $P$. aphanidermatum, $P$. ultimum, and Pythium sp., prepared as described previously, and a sporangiospore suspension of $R$. oryzae $\left(1 \times 10^{6}\right.$ spores $\left.\mathrm{ml}^{-1}\right)$ were mixed with the above seed exudates or wheat bran extract at a ratio of one part fungus suspension to three parts exudate or extract. The controls consisted of fungus and water mixes. Three aliquants $(50 \mu \mathrm{l})$ of each mix were spotted on the surface of agar plates containing $2 \%$ Noble agar and $50 \mathrm{ppm}$ rifampicin. The cultures were incubated for $24 \mathrm{~h}$ at $27^{\circ} \mathrm{C}$ in the dark, and then observed under an SZ11 stereomicroscope (Leeds Instruments Inc., San Antonio, TX) for evidence of germination and growth. Exudates from seed that were not surface sterilized also were assayed for effect on pathogen propagules.

Resistance of seed from different cotton cultivars to preemergence damping-off in seedling disease plot soil. Test tubes, containing $10 \mathrm{~g}$ each of moist $60 \%$ seedling disease plot soil and $40 \%$ washed sand mix, were planted with surface-sterilized seed of 22 different cotton cultivars. Five tubes were planted with each cultivar. The tubes were incubated for 7 days in a growth chamber at $25^{\circ} \mathrm{C}$ with a 14 -h photoperiod. Counts were made of surviving seedlings. The treatments each were replicated three times, and the experiment was repeated. Seeds of those cultivars showing $\geq 60 \%$ kill in infested soil also were planted in noninfested soil to confirm seed viability.

Biocontrol efficacy of Trichoderma spp. that do not induce phytoalexin production in cotton roots. Soil tubes (five each) of pathogen infested soil were planted with Sure-Grow 747 seed that were coated with WB+PM preparations of strain G6-4 of $T$. virens and strain TK-7 of T. koningii. Both strains lack the capacity to induce terpenoid synthesis in cotton radicles, a phenomenon that has been associated with the biological control of Rhizoctonia solani incited damping-off of cotton (9). The treatments were replicated, incubated, and counted as described in the previous section.

Statistics. All experiments were repeated at least once, with similar results, and the data from the last trials are presented here. Statistics were performed using general linear models (version 6; SAS Institute, Cary, NC).

\section{RESULTS}

Isolation and identification of cotton seedling pathogens. The colonies observed growing from the embryos of nonemerged, nontreated cotton seed of cv. Sure-Grow 747 grown in seedling disease plot soil were a mixture of Rhizopus sp. and Pythium spp. that grew well at either high $\left(37^{\circ} \mathrm{C}\right)$ or low $\left(13^{\circ} \mathrm{C}\right)$ temperature. The colonies growing from the embryos of seed treated with Metalaxyl at planting were of a high-temperature Rhizopus sp. No Pythium spp. were observed growing from these embryos. Critical examination of the Rhizopus isolate showed that its morphological and temperature characteristics were consistent with those exhibited by the species $R$. oryzae (3). The Pythium spp. isolated could be separated on the basis of their temperature parameters. One grew well at $37^{\circ} \mathrm{C}$, whereas the others did not grow at all. The high-temperature isolate exhibited the morphological and temperature characteristics associated with $P$. aphanidermatum (3). One isolate, which grew only at low to moderate temperatures, did not produce any sexual structures and could not be identified to species. It is, therefore, referred to only as Pythium $\mathrm{sp}$. The final low- to moderate-temperature isolate exhibited the morphological characteristics of the species P. ultimum (3).

Confirmation of isolate pathogenicity. The percent kills of Sure-Grow 747 seed planted in noninfested field soil that was subsequently infested with $R$. oryzae, $P$. aphanidermatum, Pythium sp., or P. ultimum were 93, 47, 73, and 93\%, respectively. The 
percent kill of seed in noninfested field soil was $0 \%$. Examination of the morphology and temperature parameters of the colonies growing from seed harvested from pathogen-infested soil tubes showed that they were the same species as those used to artificially infest the soil. These results indicate that all four isolates were pathogenic to cotton. Seed treatment with Metalaxyl protected seedlings from disease incited by the Pythium spp., but not from $R$. oryzae.

Effect of seed treatment, cotton cultivar, and soil amendment on preemergence damping-off. The percent kills in naturally infested cotton field soil of treated and untreated SureGrow 747 seed and untreated Stoneville 213 seed are given in Table 1. The percent kill of untreated Sure-Grow 747 was very high (93 to $100 \%$ ) in both nonamended and amended soils. Metalaxyl treatment of Sure-Grow 747 seed gave only partial control of preemergence damping-off in both nonamended and amended soils. Those seed treated with G-6, G6-5, TVL-30, or Tvl-35 preparations gave effective disease control in nonamended soil, but they were not effective in soil amended with wheat bran. Seed treated with autoclaved preparations of G-6 or Tvl-30 were not protected from the disease. The percent kill of untreated Stoneville 213 seed was only $7 \%$ in nonamended soil, but this rose to $93 \%$ in soil amended with wheat bran. These results indicate that Sure-Grow 747 is highly susceptible to seedling disease, that seed treatment with Metalaxyl gives only partial control in this circumstance, and that seed treatment with the tested biologicals is effective in controlling the disease. The results also indicate that Stoneville 213 is highly resistant to the seedling disease pathogens in this soil. However, the protection provided by the biological treatments or cultivar resistance could be negated by soil amendment with wheat bran.

Effect of seed exudates and wheat bran extract on pathogen propagules. Microscopic examination of mixes of seed exudates or wheat bran extract and mycelial macerates or sporangiospore suspension spotted on Noble agar, showed the following effects. Sure-Grow 747 seed exudate and wheat bran extract stimulated the germination and growth of sporangiospores of $R$. oryzae and the macerates from isolates $P$. aphanidermatum, Pythium sp., and $P$. ultimum. Seed exudate from Stoneville 213 and the water control did not stimulate the germination and growth of any of the fungal preparations. These results suggest that stimulation of pathogen propagule germination and growth by seed exudate or wheat bran extract may be associated with seedling disease development.

Resistance of cotton cultivars to preemergence damping-off in infested soil. The percent kill of cotton seedlings in pathogeninfested soil varied with the cotton cultivar (Table 2). Of the 22 cultivars tested, 12 gave a percent kill of $47 \%$ or more. Cvs. Acala SJ-2. Acala Maxxa, Acala Maxxa GTO, and Sure-Grow 747 were especially susceptible to seedling disease. Those cultivars that were most resistant to preemergence damping-off were Deltapine 20B, Deltapine 50, Deltapine 5415, Paymaster 1220 BG/RR, Acala 1517-91, and Tamcot Sphinx. Those cultivars showing a high percent kill in infested soil gave good germination and growth when planted in noninfested soil (80 to 100\%).

Biocontrol efficacy of Trichoderma spp. that do not induce terpenoid synthesis in cotton roots. Both strains G6-4 of $T$. virens and TK-7 of T. koningii, which are deficient for induction of terpenoid synthesis in cotton roots, gave effective biological control (87 and 93\%, respectively) of preemergence damping-off of Sure-Grow 747 in pathogen-infested soil.

\section{DISCUSSION}

The high rate of preemergence damping-off that occurs with some cotton cultivars in soil from the seedling disease plots at College Station, TX, can be attributed to the presence of the four pathogens that were cultured from diseased seed and seedlings.
These pathogens are $P$. aphanidermatum, $P$. ultimum, Pythium $\mathrm{sp}$., and $R$. oryzae. Seed treatment of susceptible cv. Sure-Grow 747 with Metalaxyl effectively controls disease incited by the Pythium spp., but it does not control disease incited by $R$. oryzae and is only partially effective in controlling damping-off in seedling disease plot soil. This implies that the symptoms observed in the seedling disease plots are due, primarily, to the activities of $R$. oryzae. This fungus has been isolated from field-infected cotton seed at harvest (14) and has been associated with postharvest seed deterioration of cotton (5) under the name R. arrhizus. However, this is the first report of this fungus as a soilborne seedling disease pathogen of cotton. The name of this fungus has subsequently been changed to $R$. oryzae (3).

The WB+PM preparations of T. virens strains G-6 and G6-5 and the $T$. virens $\times T$. longibrachiatum hybrid strains Tvl-30 and Tvl35 were effective in controlling all four pathogens isolated from the seedling disease plots. These strains were all effective, even though some were deficient for antibiotic activity (Tvl-30 and Tvl-35) or antibiotic activity and mycoparasitism (G6-5). This indicates that mechanisms other than antibiosis or mycoparasitism are being employed by these biocontrol agents to effect disease control. The biocontrol efficacy against preemergence dampingoff exhibited by strains G6-4 and TK-7, strains that do not induce terpenoid synthesis in cotton roots (9), also indicates that this mechanism is not of primary importance in the control of seedling disease incited by Pythium spp. and $R$. oryzae.

An alternative mechanism of biological control to those described above might be the metabolism of nutrients from germinating seed by the biocontrol agent. Metabolism of these compounds would render them unavailable to the pathogen. This concept is suggested by the work of Nelson (11), who demonstrated the effect of seed exudates on the germination of $P$. ultimum sporangia, and by the work of Green et al. (4), who suggested that biological control by $T$. harzianum involved competition with $P$. ultimum for substrates from the seed coat and wounded or infected root tissue. It is further supported by work in this article, where it was shown that extracts from wheat bran or exudates from susceptible cotton cv. Sure-Grow 747 would support the germination and growth of propagules of the four pathogens studied, but that exudates from resistant cv. Stoneville 213 would not. This

TABLE 2. Resistance of cotton cultivars to preemergence damping-off after planting in naturally infested seedling disease plot soil and incubation at $25^{\circ} \mathrm{C}$ for 7 days

\begin{tabular}{lc}
\hline Cotton cultivar & Percent kill in pathogen-infested soil ${ }^{\mathrm{z}}$ \\
\hline Deltapine 33B & $53 \pm 6$ \\
Deltapine 35 & $47 \pm 6$ \\
Deltapine 20B & $0 \pm 0^{*}$ \\
Deltapine 50 & $13 \pm 6^{*}$ \\
Deltapine 51 & $47 \pm 6$ \\
Deltapine 5409 & $27 \pm 6$ \\
Deltapine 5415 & $13 \pm 0^{*}$ \\
Deltapine 5690 & $60 \pm 6$ \\
Stoneville BXN 47 & $27 \pm 6$ \\
Stoneville 474 & $53 \pm 6$ \\
Paymaster HS26 & $60 \pm 6$ \\
Paymaster 1220 BG/RR & $7 \pm 6^{*}$ \\
Paymaster 1244 RR & $3 \pm 6^{*}$ \\
Acala SJ-2 & $93 \pm 6$ \\
Acala Maxxa & $87 \pm 0$ \\
Acala Maxxa GTO & $67 \pm 6$ \\
Acala 1517-91 & $20 \pm 6^{*}$ \\
Acala 1517-95 & $53 \pm 0$ \\
Tamcot Sphinx & $0 \pm 0^{*}$ \\
Sure-Grow 125 & $33 \pm 6$ \\
Sure-Grow 501 & $60 \pm 0$ \\
Sure-Grow 747 & $93 \pm 6$ \\
\hline Numbers given are & \\
\hline
\end{tabular}

${ }^{\mathrm{z}}$ Numbers given are the means of three replications. Asterisks indicate cotton cultivars most resistant to preemergence damping-off. 
concept is also supported by the fact that heat killing of the biocontrol agent prior to seed treatment of Sure-Grow 747 with the preparation, or amendment of infested soil with wheat bran prior to planting with resistant Stoneville 213, will render both cultivars susceptible to the disease.

Of the cotton cultivars tested for resistance to preemergence damping-off in this study, 50\% were susceptible to the pathogens found in soil from the seedling disease plots. Metalaxyl seems to be only partially effective in controlling this disease; therefore, it would be prudent, when growing a susceptible cultivar, to treat the seed with an effective Trichoderma strain or to use a combination of Metalaxyl and a biocontrol agent.

The data derived from this study support the following hypotheses. Preemergence damping-off of cotton seedlings in soil infested with Pythium spp. and $R$. oryzae is initiated by the induction of pathogen propagule germination and growth with compounds emanating from germinating cotton seed. Effective biocontrol strains of Trichoderma spp. prevent initiation of the preemergence damping-off syndrome by metabolizing pathogen propagule germination stimulants that emanate from the germinating cotton seed. Cotton cultivars vary widely in their susceptibility to preemergence damping-off, and this is related to the release by their seed of compounds that stimulate germination of pathogen propagules. Although disease resistance is the culmination of many factors, it is, in part, associated with little or no release of pathogen propagule stimulants by germinating seed.

Although both the compounds in seed exudate and in wheat bran extract stimulate pathogen propagule germination, there is no other evidence to suggest that they are the same. They may be, however, and research is currently underway to isolate and identify these stimulants.

\section{ACKNOWLEDGMENTS}

Mention of trade names or commercial products in this publication is solely for the purpose of providing specific information and does not imply recommendation or endorsement by the U.S. Department of Agriculture.

\section{LITERATURE CITED}

1. Ayers, W. A., and Lumsden, R. D. 1975. Factors affecting production and germination of oospores of three Pythium spp. Phytopathology 65:1094-1100.
2. Blasingame, D., and Mukund, V. P. 2001. Cotton disease loss estimate committee report. Pages 102-103 in: Proc. Beltwide Cotton Conf. Natl. Cotton Counc. Am. F. Duggar and D. A. Richter, eds. Nashville, TN.

3. Domsch, K. H., Gams, W., and Anderson, T. H. 1980. Pages 679-697 and 701-709 in: Compendium of Soil Fungi, Vol. 1. Academic Press, New York.

4. Green, H., Heiberg, N., Lejbolle, K., and Jensen, D. F. 2001. The use of a GUS transformant of Trichoderma harzianum, strain T3a, to study metabolic activity in the spermosphere and rhizosphere related to biocontrol of Pythium damping-off and root rot. Eur. J. Plant Pathol. 107:349-359.

5. Halloin, J. M. 1975. Postharvest infection of cottonseed by Rhizopus arrhizus, Aspergillus niger, and Aspergillus flavus. Phytopathology 65: 1229-1232.

6. Hillocks, R. J. 1992. Seedling diseases. Pages 13-17 in: Cotton Diseases. R. J. Hillocks, ed. CAB International, Wallingford, U.K.

7. Howell, C. R. 1982. Effect of Gliocladium virens on Pythium ultimum, Rhizoctonia solani, and damping-off of cotton seedlings. Phytopathology 72:496-498.

8. Howell, C. R. 1991. Biological control of Pythium damping-off of cotton with seed-coating preparations of Gliocladium virens. Phytopathology 81:738-741.

9. Howell, C. R., Hanson, L. E., Stipanovic, R. D., and Puckhaber, L. S. 2000. Induction of terpenoid synthesis in cotton roots and control of Rhizoctonia solani by seed treatment with Trichoderma virens. Phytopathology 90:248-252.

10. Liu, L. 1997. Altered root exudation and suppression of induced lignification as mechanisms of predisposition by glyphosate of bean roots (Phaseolus vulgaris L.) to colonization by Pythium spp. Physiol. Mol. Plant Pathol. 51:110-127.

11. Nelson, E. B. 1994. Nutritional factors affecting responses of sporangia of Pythium ultimum to germination stimulants. Phytopathology 84:677683.

12. Nelson, E. B., and Craft, C. M. 1989. Comparative germination of culture-produced and plant produced sporangia of Pythium ultimum in response to soluble seed exudates and exudate components. Phytopathology 79:1009-1013.

13. Rutledge, T. R. 1997. Extracted fatty acids from Gossypium hirsutum stimulatory to the seed-rotting fungus, Pythium ultimum. Phytochemistry 46:77-82.

14. Simpson, M. E., Marsh, P. B., Merola, G. V., Feretti, R. J., and Filsinger, E. C. 1973. Fungi that infect cottonseeds before harvest. Appl. Microbiol. 28:608-613.

15. Thomson, W. T. 1997. Pages 178-179 in: Agricultural Chemicals. Book IV-Fungicides. W. T. Thomson, ed. Thomson Publications, Fresno, CA.

16. Wilhite, S. E., Lumsden, R. D., and Straney, D. C. 1994. Mutational analysis of gliotoxin production by the biocontrol fungus Gliocladium virens in relation to suppression of Pythium damping-off. Phytopathology 84:816-821. 